\title{
Profil Kemampuan Siswa SMP dalam Memecahkan Masalah Matematika Open- Ended Berdasarkan Kemampuan Prasyarat Tinggi
}

\author{
Zakiyah Anwar, Rahmatullah Bin Arsyad \\ Universitas muhammadiyah Sorong/ Pendidikan Matematika, FKIP UM Sorong \\ e-mail: ${ }^{1}$ zakiyahanwar3377@gmail.com, ${ }^{2}$ rahmatullahbinarsyad@gmail.com
}

\begin{abstract}
Abstrak
Penelitian ini merupakan penelitian deskriptif kualitatif yang pelaksannannya di SMP YPK Syaloom kota Sorong. Penelitian ini bertujuan mendeskripsikan profil kemampuan siswa dalam memecahkan masalah matematika open-ended berdasarkan kemampuan Prasyarat tinggi. Instrumen yang digunakan dalam penelitian ini adalah (1) tes GEFT, (2) tes kemampuan prasyarat SPLDV, (3) tes pemecahan masalah open-ended, (4) dan tes wawancara, baik yang terstruktur maupun yang tidak terstruktur. Subjek penelitian dibedakan berdasarkan tingkat kemampuan prasyarat prasyarat tinggi dan gaya kognitif gaya Field Dependen dan Field Independen. Hasil penelitian ini adalah (1) subjek penelitian dengan kemampuan prasyarat tinggi gaya kognitif field dependen, menunjukkan kemampuan yang baik dalam memahami masalah dengan tepat, merencanakan pemecahan, menyelesaikan masalah sesuai dengan rencana dan memeriksa kembali hasil yang diperoleh. Subjek dapat menyelesaikan masalah SPLDV dengan metode eliminasi, gabungan, dan metode grafik, (2) subjek penelitian dengan kemampuan prasyarat tinggi gaya kognitif field independen, dapat memahami masalah dengan tepat, melaksanakan pemecahan sesuai rencana, dan memeriksa kembali hasil yang diperoleh. Subjek dapat menyelesaikan masalah SPLDV dengan metode eliminasi, subtitusi, gabungan. Penelitian ini sangat membantu pendidik dalam memberikan soal masalah matematika berdasarkan kemampuan yang dimiliki oleh siswa.
\end{abstract}

Kata kunci : Open- Ended, Pemecahan masalah, gaya kognitif

\begin{abstract}
This research is a qualitative descriptive study that was implemented at the Sorong City YPK Syaloom Middle School. This study aims to describe the profile of students' ability to solve open-ended math problems based on high ability. The instruments used in this study were (1) GEFT test, (2) SPLDV prerequisite ability test, (3) open-ended problem solving test, (4) and interview test, both structured and unstructured. The research subjects were differentiated based on the level of ability of the high prerequisite prerequisites and the cognitive style of the Field of Dependent and Independent Field styles.

The results of this study are (1) the research subjects with the ability of high field dependent cognitive style prerequisites, show good ability to understand the problem correctly, plan solutions, solve problems in accordance with the plan and reexamine the results obtained. Subjects can solve SPLDV problems by elimination, combination, and graphic methods, (2) research subjects with independent cognitive style field prerequisite abilities, can understand problems correctly, implement solutions according to plan, and re-examine the results obtained. Subjects can solve SPLDV problems by elimination, substitution, combination methods. This research is very helpful for educators in providing math problems based on the abilities possessed by students.
\end{abstract}

Keywords: Open-Ended, Problem solving, cognitive style

\section{PENDAHULUAN}

Kemampuan tingkat kecakapan memecahkan masalah antara siswa yang satu dengan yang lain berbeda. Sama halnya dengan taraf kecerdasan, atau kemampuan berpikir kreatif siswa juga dapat berbeda dalam cara memperoleh, menyimpan serta menerapkan pengetahuan. Siswa dapat berbeda dalam tingkat kemampuan prasyarat, cara pendekatan terhadap situasi belajar, bagaimana cara menerima, mengorganisasi, menghubungkan pengalaman-pengalaman mereka, dalam cara mereka 
berespons terhadap metode pengajaran yang mereka alami. Ada yang cepat, sedang, dan ada pula yang sangat lambat. Oleh karena itu, mereka seringkali harus menempuh cara berbeda untuk bisa memahami sebuah informasi atau pelajaran yang sama.

Menurut Slameto (2003:160), perbedaan antar pribadi menyangkut sikap, pilihan atau strategi secara stabil yang menentukan cara - cara khas seseorang dalam menerima, mengingat, berpikir, dan memecahkan masalah disebut dengan "cognitive styles" atau gaya kognitif yang terdiri dari Field Independen (FI) dan Field Dependen (FD). Umumnya siswa yang field-independent kurang dipengaruhi oleh lingkungan, atau bahkan tidak dipengaruhi lingkungan. Adapun gaya belajar fielddependent kebalikan dari gaya belajar field-independent. Individu dengan gaya belajar ini menerima sesuatu secara global dan mengalami kesulitan dalam memisahkan diri dari keadaan sekitar, cenderung mengenal dirinya sebagai bagian dari suatu kelompok. Dalam interaksi sosial mereka cenderung untuk lebih perspektif dan peka. Umumnya siswa dengan gaya belajar seperti ini sangat dipengaruhi oleh lingkungan atau bergantung pada lingkungan.

Secara konseptual open-ended problem dapat dirumuskan sebagai masalah atau soal-soal matematika yang dirumuskan sedemikian rupa sehingga memiliki beberapa atau bahkan banyak solusi yang benar, dan terdapat banyak cara untuk mencapai solusi itu. Pembelajaran dengan pendekatan Open-ended diawali dengan memberikan masalah terbuka kepada siswa. Kegiatan pembelajaran harus mengarah dan mengantarkan siswa dalam menjawab masalah dengan banyak cara serta mungkin juga dengan banyak jawaban yang benar, sehingga merangsang kemampuan intelektual dan pengalaman serta kreativitas siswa dalam proses menemukan sesuatu yang baru.

Penerapan pendekatan Open-ended dalam pembelajaran matematika dapat memberikan kesempatan kepada siswa untuk mengembangkan kegiatan kreatif dan berpikir matematika secara simultan. Dalam menyelesaikan suatu permasalahan siswa tidak terpaku hanya pada satu jawaban yang mungkin. Oleh karena itu, hal yang harus diperhatikan adalah memberikan kesempatan dan kebebasan yang seluas-luasnya kepada siswa untuk berpikir dalam mencari alternatif pemecahan dari suatu masalah yang dihadapi sesuai dengan kemampuan, sikap, dan minat yang dimilikinya sehingga pada akhirnya akan membentuk intelegensi matematika mereka. Guru harus dapat memanfaatkan keragaman cara untuk menyelesaikan masalah itu, untuk memberi pengalaman kepada siswa dalam menemukan seseuatu yang baru berdasarkan pengetahuan, keterampilan, dan kemampuan berpikir matematik yang sudah dimiliki siswa. 


\section{Tipe Field Independent (FI) dan Field Dependent (FD)}

Gaya kognitif terbagi atas dua bagian, yakni Field Independent (FI) dan Filed Dependent (FD). Sejak 1948, Witkin telah memulai mengembangkan alat ukur untuk membedakan tipe-tipe siswa berdasarkan gaya kognitif (Witkin,1977:2). Witkin menyatakan bahwa individu yang bersifat analitik adalah individu yang merasakan lingkungan ke dalam komponen-komponennya, kurang bergantung pada lingkungan atau kurang dipengaruhi oleh lingkungannya. Individu ini dikatakan termasuk gaya kognitif FI. Sedangkan individu yang bersifat global adalah individu yang menfokuskan pada lingkungan secara keseluruhan, didominasi atau dipengaruhi lingkungan. Individu tersebut dikatakan termasuk gaya kognitif FD.

Individu yang sulit melepaskan diri dari keadaan yang mengacaukannya, yaitu individu FI akan menemukan kesulitan dalam masalah-masalah yang menuntut keterangan di luar konteks. Individu yang FD akan mengorganisasikan apa yang diterimanya sebagaimana yang disajikan, sedangkan pada individu yang field independent, akan mampu menanggulangi apa yang diterimanya dengan mencari komponen-komponen yang dapat diletakkan pada permasalahan yang dihadapinya.

Individu FI mempunyai kecenderungan dalam mengamati sesuatu bagian perbagian. Kemampuan tersebut akan tampak sangat kuat jika yang diamati merupakan obyek yang terstruktur. Individu FD akan menemui kesulitan dalam mengamati bagian-bagian dari obyek yang tidak berstruktur. Berdasarkan hal tersebut, individu yang field independent cenderung sulit memecahkan masalah sosial dan bahasa, karena obyek sosial dan bahasa merupakan objek yang rumit dan kurang terstruktur.

Individu FD dalam mengamati sesuatu cenderung secara keseluruhan, dan cenderung mendapatkan kesulitan dalam memecahkan masalah sosial. Hal tersebut karena individu FD tidak memperhatikan bagian perbagian dari obyek yang diamatinya. Sehingga walaupun obyek sosial adalah obyek yang rumit dan kurang berstruktur, individu FD tidak mempermasalahkannya.

Kajian ini merupakan hasil penelitian yang telah dilaksanakan sebelumnya dan dijadikan sebagai landasan dalam penelitian. Dalam hal ini, peneliti menemukan beberapa karya ilmiah dari beberapa jurnal yang sudah ada yang akan peneliti gunakan sebagai acuan dalam meneliti, antara lain: (1) Yurizka Melia Sari (2012) dalam penelitiannya mengatakan Profil Kemampuan Siswa SMP dalam Memecahkan Masalah Matematika Open-Ended Berdasarkan Kemampuan Tinggi Subjek penelitian yang memiliki kemampuan matematika tinggi, dalam tahap memahami masalah, subjek menuliskan 
beberapa yang diketahui pada lembar jawaban dan dapat menjelaskan apa yang diketahui dari soal dan apa yang ditanyakan secara tepat.subjek berkemampuan sedang dapat menyebutkan apa yang diketahui dan maksud dari permasalahan tersebut dengan tepat, meskipun subjek tidak menuliskan apa yang diketahui di lembar jawaban. Subjek penelitian yang memiliki kemampuan matematika rendah, dalam hal memahami, subjek tidak tepat dalam menjelaskan maksud dari masalah tersebut dan hanya sekedar membaca soal. (2) Mustikasari, M., Zulkardi, Z., \& Aisyah (2012) dalam penelitiannya mengatakan Prototype soal open-ended yang dikembangkan memilki efek potensial yang baik. Hal ini terlihat dengan munculnya beragam solusi jawaban siswa, dan rata-rata prosentase siswa yang memiliki kemampuan berpikir kreatif adalah $77,83 \%$, serta nilai rata-rata siswa yang memperoleh skor $\geq 60$ (kategori positif) dari hasil dua kali tes soal open-ended rata-rata mencapai 79,8\%.

Penelitian bertujuan untuk mengungkapkan gambaran kemampuan siswa Sekolah Menengah Pertama (SMP) dalam memecahkan masalah matematika open-ended, ditinjau dari perbedaan tingkat kemampuan prasyarat dan gaya kognitif.

\section{METODE PENELITIAN}

Jenis Penelitian ini adalah Penelitian deskriptif kualitatif berdasarkan pada wawancara berbasis tugas (the task-based interview). Data yang dianalisis adalah hasil pekerjaan siswa dalam menyelesaikan masalah open-ended dan hasil wawancara. Penelitian ini dilaksanakan di SMP YPK Syaloom Kota Sorong. Pemilihan SMP YPK Syaloom berdasarkan pertimbangan bahwa sekolah tersebut mempunyai kualitas menengah; artinya SMP YPK Syaloom termasuk sekolah bukan yang terbaik dan bukan yang terjelek. Kemampuan prasyarat matematika siswa diperoleh dari hasil tes kemampuan siswa untuk materi prasyarat SPLDV dan didukung oleh informasi dari guru. Skor untuk tes kemampuan prasyarat yang diperoleh diurutkan dalam kategori tinggi $(75<\mathrm{x} \leq 100)$,. Sedangkan untuk skor tes GEFT digunakan untuk mengelompokkan subjek ke dalam FI dan FD. Skor dengan gaya kognitif $(10 \leq x \leq 18)$ disebut memiliki gaya kognitif FI, Skor dengan gaya kognitif $(0 \leq \mathrm{x} \leq 9)$ disebut memiliki gaya kognitif FD. Instrumen dan teknik pengumpulan data yang digunakan adalah : a) tes kemampuan prasyarat dan tes kemampuan pemecahan masalah matematika open-ended; $b$ ) tes GEFT (Group Embedded Figures Test); c) wawancara. 


\section{HASIL PENELITIAN DAN PEMBAHASAN}

Penelitian yang menggambarkan apa adanya tentang subjek penelitian yang berhubungan dengan kemampuan pemecahan masalah SPLDV berdasarkan tingkat kemampuan prasyarat dan gaya kognitif Siswa SMP YPK Syaloom. Pengumpulan data pada penelitian ini digunakan tes gaya kognitif siswa, kemampuan prasyarat SPLDV, serta tes kemampuan menyelesaikan masalah open-ended. Hasil tes gaya kognitif siswa pada penelitian ini diperlukan untuk mengelompokkan siswa berdasarkan gaya kognitif yang dimilikinya, yaitu kelompok siswa dengan gaya kognitif field-independent (FI) dan kelompok siswa dengan gaya kognitif field-dependent (FD).

\section{A. Proses dan Hasil Penelitian Tahap Persiapan}

\section{Persiapan instrumen penelitian}

Berdasarkan hasil observasi calon subjek penelitian, maka dibutuhkan instrumen-instrumen sebagai berikut: (1) alat ukur untuk memetakan tipe gaya kognitif (tes GEFT), (2) tes kemampuan prasyarat SPLDV, (3) tes pemecahan masalah open-ended. Untuk menggunakan semua instrumen ini, maka kemudian diserahkan kepada validator untuk memvalidasi tentang kelayakan instrumen tersebut digunakan.

\section{Pemilihan subjek penelitian}

Pemilihan subjek penelitian berdasarkan pertimbangan pada rumusan masalah, diperoleh 6 kelompok sel yang telah terbagi ke dalam dua kelompok besar yaitu kelompok siswa dengan gaya kognitif field dependent dan gaya kognitif field independent. Setiap kelompok tersebut masing masing dibagi lagi menjadi kelompok dengan kemampuan prasyarat tinggi. Sehingga kelompok yang diperoleh adalah kemampuan prasyarat tinggi dengan gaya FI, kemampuan prasyarat tinggi dengan gaya FD. Dalam penelitian ini peneliti fokus pada kemampuan prasyarat tinggi dengan gaya FI, kemampuan prasyarat tinggi dengan gaya FD

Pada pemilihan subjek utama, selain memperhatikan tingkat kemampuan prasyarat dan gaya kognitif juga mempertimbangkan masukan guru matematika yang mengajar pada keempat kelas sampel.

\section{B. Proses dan Hasil Penelitian Tahap Pembahasan}

Berdasarkan keseluruhan analisis wawancara di atas, dapat dituliskan suatu profil kemampuan siswa dalam memecahkan masalah matematika open-ended ditinjau dari perbedaan tingkat kemampuan prasyarat Tinggi sebagai berikut: 
1. Siswa dengan kemampuan prasyarat tinggi gaya kognitif field dependen $\left(\mathrm{R}_{1}\right)$

Subjek $\mathrm{R}_{1}$ sebagai satu-satunya responden yang berada pada sel kemampuan prasyarat SPLDV tinggi dengan gaya kognitif field dependent mampu memahami permasalahan dan mampu mengungkapkan konsep yang diketahui dengan tepat. Ia dapat melaksanakan apa yang direncanakannya dengan baik dan benar walaupun tidak menampilkan seluruh rencana yang ada dipikirannya. Subjek $\mathrm{R}_{1}$ dapat menyelesaikan masalah SPLDV dengan berbagai alternatif jawaban seperti metode eliminasi, gabungan, dan metode grafik. Subjek $\mathrm{R}_{1}$ dapat menunjukkan cara memeriksa kebenaran jawabannya dengan benar pula.

Dalam memecahkan masalah SPLDV, subjek $\mathrm{R}_{1}$ mengikuti langkah-langkah pemecahan masalah Polya yaitu memahami masalah, merencanakan pemecahan, melaksanakan penyelesaian sesuai rencana dan memeriksa kembali hasil yang diperoleh.

2. Siswa dengan kemampuan prasyarat tinggi gaya kognitif field independent $\left(\mathrm{R}_{2}\right.$ dan $\left.\mathrm{R}_{3}\right)$

Subjek $\mathrm{R}_{2}$ dan $\mathrm{R}_{3}$ sebagai responden yang berada pada sel kemampuan prasyarat SPLDV tinggi dengan gaya kognitif field independent(FI) mampu memahami permasalahan dan mampu mengungkapkan konsep yang diketahui dengan tepat dan lugas. mereka dapat melaksanakan apa yang direncanakannya dengan baik dan benar walaupun tidak menampilkan seluruh rencana yang ada dipikirannya. Subjek $\mathrm{R}_{2}$ dan $\mathrm{R}_{3}$ dapat menyelesaikan masalah SPLDV dengan berbagai alternatif jawaban seperti metode eliminasi, subtitusi, gabungan. Untuk metode grafik, mereka tidak mampu menggambarkannya. Subjek $\mathrm{R}_{2}$ dan $\mathrm{R}_{3}$ dapat menunjukkan cara memeriksa kebenaran jawaban yang telah dikerjakan.

Dalam memecahkan masalah SPLDV, subjek $R_{2}$ dan $R_{3}$ mengikuti langkah-langkah pemecahan masalah Polya yaitu memahami masalah, merencanakan pemecahan, melaksanakan penyelesaian sesuai rencana dan memeriksa kembali hasil yang diperoleh.

C. Relevansi Hasil Pembahasan dengan Hasil Penelitian

Berdasarkan hasil penelitian di atas, secara umum dapat diketahui bahwa terjadi keselarasan antara teori yang ada dengan keadaan yang sebenarnya, khususnya pada siswa SMP YPK Syaloom sebagai subjek penelitian.

Pada hasil penelitian terlihat bahwa subjek yang berada pada tingkat kemampuan prasyarat yang sama, cenderung memiliki tingkat kemampuan pemecahan masalah yang sama pula, meskipun dengan gaya kognitif yang berbeda. Sebagai contoh, subjek dengan kemampuan 
prasyarat tinggi gaya kognitif FD memiliki kemampuan pemecahan masalah yang relatif sama subjek dengan kemampuan prasyarat tinggi gaya kognitif FI yaitu dalam hal proses pemecahan masalah menunjukkan kemampuan yang baik. Dalam arti dapat memahami masalah dengan tepat, dapat melaksanakan apa yang direncanakannya dengan baik dan benar, subjek juga dapat menyelesaikan masalah SPLDV dengan berbagai alternatif jawaban seperti metode eliminasi, subtitusi dan gabungan serta dapat menunjukkan cara memeriksa kebenaran jawabannya dengan benar pula. Dalam memecahkan masalah, subjek mengikuti langkah-langkah pemecahan masalah Polya.

D. Implikasi Hasil Penelitian

Dari hasil-hasil penelitian ini diharapkan dapat berimplikasi pada pembelajaran matematika di sekolah; (1) Pendekatan open-ended dapat dijadikan sebagai salah satu alternatif pembelajaran untuk meningkatkan kreativitas siswa, mengingat bahwa dengan memecahkan masalah openended, akan melatih kemampuan berfikir divergen, memberikan kesempatan kepada siswa untuk menginvestigasi berbagai strategi dan cara yang diyakininya sesuai dengan kemampuan yang dimilikinya untuk mengelaborasi permasalahan. Tujuannya tiada lain adalah agar kemampuan berpikir matematika siswa dapat berkembang secara maksimal. (2) Menempatkan siswa di dalam ruangan yang berbeda berdasarkan gaya kognitif mereka. Melalui penempatan ruangan yang terpisah, guru dapat memberikan pembelajaran melalui metode yang dianggap lebih efektif dan relevan untuk masing-masing gaya kognitif. Dalam hal ini, siswa dengan gaya kognitif field dependent akan lebih efektif jika diajar dengan metode discovery (penemuan), sedangkan siswa dengan gaya kognitif field independent lebih efektif jika diajar dengan metode expository (ekspositori).

\section{SIMPULAN}

Profil Kemampuan Siswa Dalam Memecahkan Masalah Matematika Open-Ended Ditinjau dari Perbedaan Tingkat Kemampuan Prasyarat Tinggi diperoleh sebagai berikut: Profil subjek penelitian yang memiliki kemampuan prasyarat tinggi gaya kognitif field dependen, dalam hal proses pemecahan masalah menunjukkan kemampuan yang baik. Dalam arti dapat memahami masalah dengan tepat, dapat melaksanakan apa yang direncanakannya dengan baik dan benar, subjek juga dapat menyelesaikan masalah SPLDV dengan berbagai alternatif jawaban seperti metode eliminasi, 
gabungan, dan metode grafik, dan dapat menunjukkan cara memeriksa kebenaran jawabannya dengan benar pula. Dalam memecahkan masalah, subjek mengikuti langkah-langkah pemecahan masalah Polya. Profil subjek penelitian yang memiliki kemampuan prasyarat tinggi gaya kognitif field independen, dalam hal proses pemecahan masalah menunjukkan kemampuan yang baik, mampu mengungkapkan konsep yang diketahui dengan tepat dan lugas. Dalam arti dapat memahami masalah dengan tepat, dapat melaksanakan pemecahan sesuai dengan rencana dengan baik dan benar. Subjek juga dapat menyelesaikan masalah SPLDV dengan berbagai alternatif jawaban seperti metode eliminasi, gabungan, dan subtitusi. Subjek juga dapat menunjukkan cara memeriksa kebenaran jawabannya dengan benar pula.

\section{DAFTAR PUSTAKA}

Asriah, Asri Nurlaelatul. 2011. Meningkatkan Kemampuan Berpikir Kreatif Matematika Peserta Didik Sekolah Menengah Pertama (SMP) dengan pendekatan Open-Ended. Skripsi. Tasikmalaya: FKIP, Universitas Siliwangi.

Desmita.,2009. Psikologi Perkembangan Peserta Didik, Bandung: PT Remaja Rosdakarya., h.145

Mustikasari, M., Zulkardi, Z., \& Aisyah, N. (2014). Pengembangan Soal-soal Open-Ended Pokok Bahasan Bilangan Pecahan di Sekolah Menengah Pertama. Jurnal Pendidikan Matematika, 4(2).

Ngilawajan, D. A. 2016. Proses Berpikir Siswa SMA dalam memecahkan masalah matematika materi turunan ditinjau dari gaya kognitif field independent dan field dependent. Pedagogia, 2(1), 7183.

Polya, G. 1973. How to Solve It: A New Aspect of Mathematical Method. New Jersey Pronceton University Press

Rahman, 2009. Profil Pengajuan Masalah Matematika Berdasarkan Gaya Kognitif. Surabaya: PPs UNESA.

Sari, Y. M. 2012. Profil Kemampuan Siswa SMP Dalam Memecahkan Masalah Matematika OpenEnded Materi Pecahan Berdasarkan Tingkat Kemampuan Matematika. MATHEdunesa,1(1). ----., \& Pramesti, G. (2013). Penerapan Pendekatan Open-Ended Dalam Pembelajaran Matematika Untuk Meningkatkan Kemampuan Berpikir Matematis Siswa Ditinjau Dari Respon Siswa Terhadap Pembelajaran Tahun Ajaran 2011/2012. Jurnal Pendidikan Matematika Solusi, 1(1).

Shimada, S dan Becker JP. 1997. The Open-Ended Approach. A New Proposal for Teaching Mathematics. Virginia: NCTM.

Slameto, 2003. Belajar dan Faktor-faktor yang Mempengaruhinya. Jakarta: Rineka Cipta. 